\title{
Possible ways to improve public bus transportation in Itaperuna, Rio de Janeiro, Brazil
}

\author{
D. I. De Souza ${ }^{1,2}$, R. Rocha ${ }^{2}$ \& P. Duarte ${ }^{1}$ \\ ${ }^{1}$ Civil Engineering Department, Fluminense Federal University, Brazil \\ ${ }^{2}$ Industrial Engineering Department, \\ North Fluminense State University, Brazil
}

\begin{abstract}
In a previous paper by De Souza et al. we analyzed the transportation system by buses in the city of Rio Branco, located in the state of Acre, Brazil. In this work the main objective is to analyze the quality of service of the public bus company operating in the city of Itaperuna, in the state of Rio de Janeiro. Itaperuna has around 180,000 inhabitants and the bus service is supplied by only one public bus company. This analysis will be based on the opinion of the bus users with the objective of determining their degree of satisfaction with the service available. Then we will be able to determine the best way to improve the quality of the service provided by Itaperuna's bus company.
\end{abstract}

Keywords: public transportation, Itaperuna's bus company, quality of service, passenger opinion, service cost, time schedule, efficiency.

\section{Introduction}

The urban transportation system of Brazilian cities relies heavily on buses. Therefore it is a major concern for authorities to find ways to improve the efficiency of the bus service delivered to the population. Itaperuna, a city in the state of Rio de Janeiro, Brazil, is not an exception to this rule. It has around 180,000 inhabitants and the bus service is supplied by only one public bus company. Needless to say, the city's transportation system is highly dependent on this bus company.

In the last few years Itaperuna has shown a rapid population increase due to the economic development of Rio de Janeiro. Even with this fact in mind, it is 
noticeable that the volume of paying passengers using the local bus service has been falling year after year. Several factors such as personal cars; travel by bicycles and motorcycles; private buses and passenger dissatisfaction with bus service can be contributing to this situation.

In this work the main objective is to analyze the quality of service of the public bus company operating in the city of Itaperuna. This analysis will be based on the opinion of the bus users with the objective of determining their degree of satisfaction with the service available. With the outcome of this evaluation we will be able to determine the best way to improve the quality of service provided by Itaperuna's bus company in terms of manpower, service cost, time schedule, etc. This work will also identify the profile of the bus company's customers.

\section{Collective transportation system in Brazil}

According to the National Urban Transport Association [2] "in Brazil, on average, the public transportation system is carrying $40 \%$ fewer passengers then they carried in 1995." This situation creates a vicious circle, shown in Figure 1.

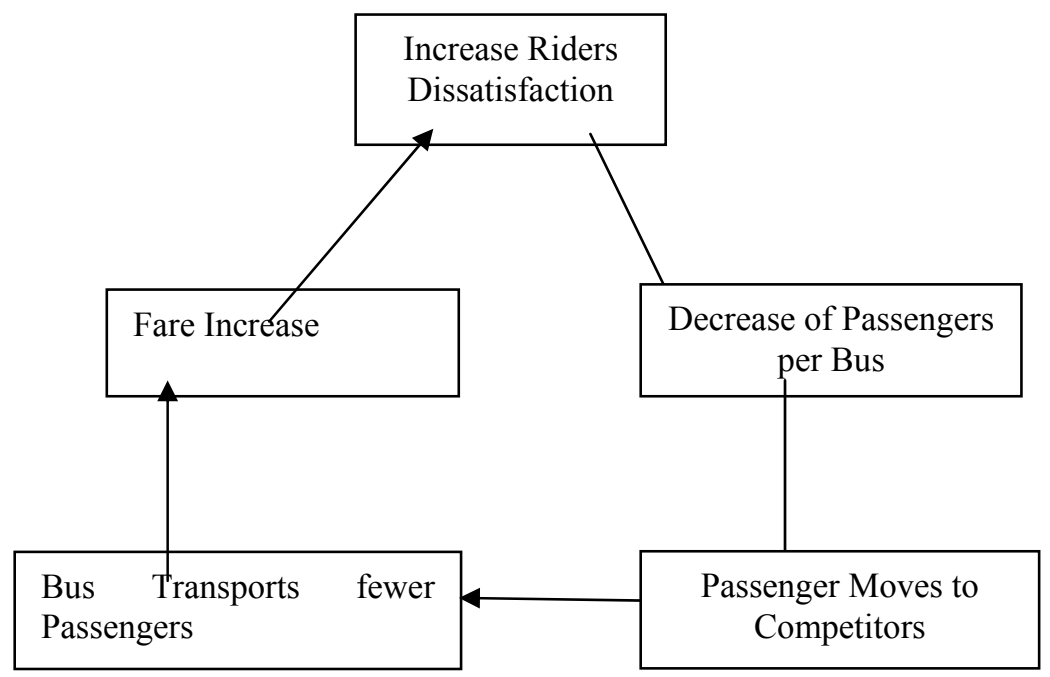

Figure 1: $\quad$ The vicious circle faced by public bus companies in Brazil.

The NPK (Number of Passengers per Kilometer,) in 2003 was approximately $66 \%$ lower than in the beginning of the 90's, before the boom in the car industry and the creation of illegal (not authorized) bus or van transport. Another indicator of the decline in bus transport is the average number of passengers transported by day per bus, which at the beginning of the 90's was 600 and has declined to 400 in 2004 . As the number of riders decline, the operational cost of the buses falls to the remaining passengers, who become unhappy and more willing to use other transportation options, which powers the vicious circle (National Urban Transportation Association-Yearly Report [3]) 
More recently, according to the National Urban Transport Association [4], in the state capitals the number of passengers transported per month in 2009 has shown some stabilization in relation to 2008 , even though this number is quite inferior to the one registered at the beginning of the last decade. This can be seen in Figure 2 below from the National Urban Transportation Association [4].

\section{PASSAGEIROS TRANSPORTADOS POR MÊS Abril O Outubro e 1994 a 2009 Obs: Valores da quantidade de passageiros}

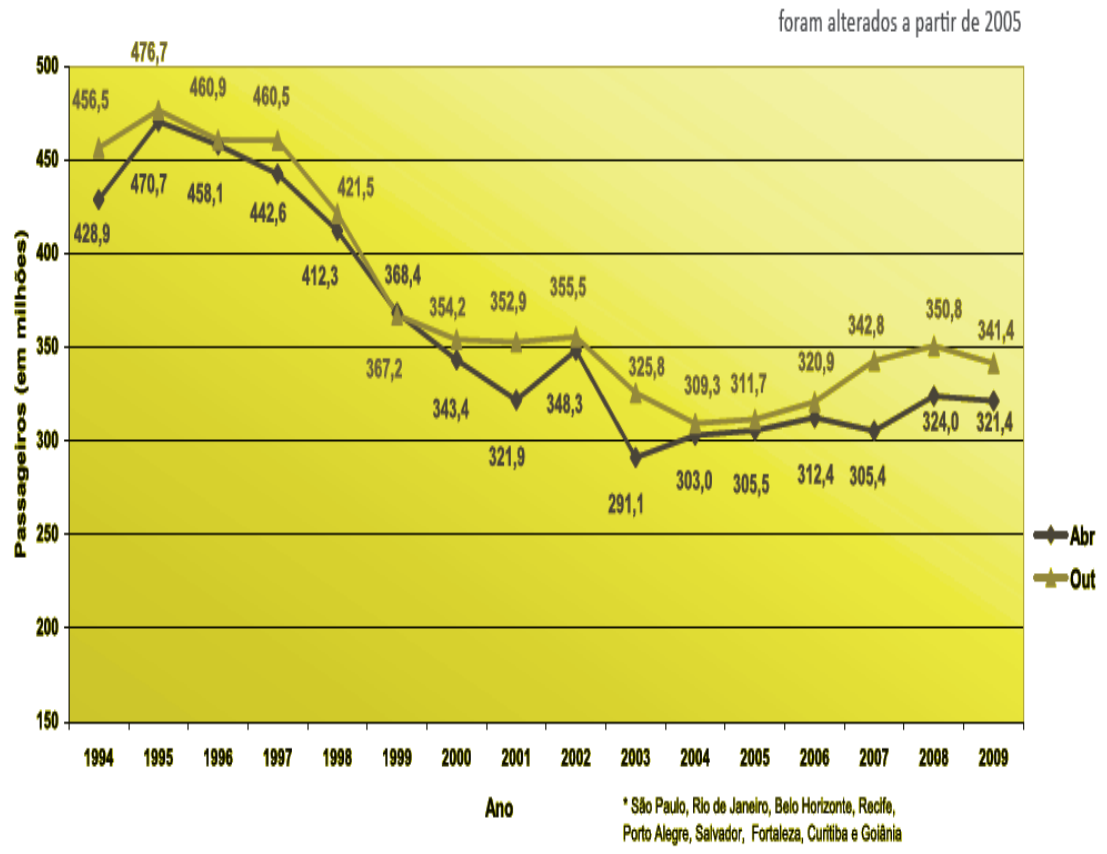

Source: National Urban Transportation Association.

Figure 2: Number of transported passengers during the months of April and October (1994-2009).

\section{Methodology}

The research method used in this work was a questionnaire asking the customer's opinion about the service given by the bus company operating in the city of Itaperuna. From the population of riders in Itaperuna, a random sample of 200 was selected. This research was carried out during the month of October 2010, in the morning, noontime, and again, in the afternoon. Table 1 below shows the bus company's user population and sample data.

The questionnaire used in this work was composed of 27 questions, 16 related to customer satisfaction with the services provided by the bus company, and 11 questions concerning the passenger profiles. It also included a space for suggestions. 
Table 1: $\quad$ Bus company's user population and sample data.

\begin{tabular}{l|l|}
\hline \multicolumn{1}{|c|}{ Population } & \multicolumn{1}{|c|}{ Sample } \\
\hline $\begin{array}{l}\text { An average of } 320,000 \text { passengers per month, or } \\
7,272 \text { passengers per day (traveling twice a day for } \\
22 \text { days per month). }\end{array}$ & $\begin{array}{l}\text { 200 passengers } \\
\text { from the existing } \\
\text { bus company } \approx 3 \%\end{array}$ \\
\hline
\end{tabular}

\section{Results of this survey}

The results of the questionnaire associated with customer satisfaction can be seen in Table 2. These results will allow us to determine the satisfaction level of all the customers in relation to each one of the items surveyed. Finally, we will present in Table 3 the profile of the bus company's customer.

\subsection{Results associated with customer satisfaction}

Table 2: Questionnaire results associated with customer satisfaction.

\begin{tabular}{|c|c|c|c|}
\hline \multirow{2}{*}{ Conditions } & \multicolumn{3}{|c|}{ Itaperuna's Bus Company } \\
\cline { 2 - 4 } & \multicolumn{2}{|c|}{ Evaluation (200 users per item) } \\
\cline { 2 - 4 } & Good & Average & Bad \\
\hline Length of time of bus trip & 32 & 99 & 69 \\
\hline Bus itinerary & 28 & 88 & 84 \\
\hline Interval between buses & 11 & 48 & 141 \\
\hline Number of buses in the users line & 22 & 80 & 98 \\
\hline Cleanliness & 78 & 101 & 21 \\
\hline Conservation & 67 & 98 & 35 \\
\hline Comfort & 30 & 108 & 62 \\
\hline Safety & 31 & 94 & 75 \\
\hline Noise and air pollution & 27 & 84 & 89 \\
\hline Fare & 5 & 5 & 190 \\
\hline Scheduling & 21 & 71 & 108 \\
\hline Employee courtesy & 69 & 91 & 40 \\
\hline Information provided to passengers & 16 & 99 & 85 \\
\hline Speed of the bus & 101 & 30 & 69 \\
\hline Average trip time & 42 & 126 & 32 \\
\hline Waiting time at the bus stop & 9 & 36 & 155 \\
\hline Total & 589 & 1,258 & 1,353 \\
\hline
\end{tabular}




\subsection{Customer profile of Itaperuna's bus company}

Table 3: Age.

\begin{tabular}{|c|c|}
\hline Age (years) & Number of customers (total of 200) \\
\hline 17 or less & 26 \\
\hline 18 to 25 & 63 \\
\hline 26 to 33 & 46 \\
\hline 34 to 41 & 30 \\
\hline 42 to 49 & 20 \\
\hline 50 to 57 & 4 \\
\hline 58 to 65 & 6 \\
\hline 66 or more & 5 \\
\hline
\end{tabular}

Table 4: $\quad$ Gender.

\begin{tabular}{|c|c|}
\hline Gender & $\begin{array}{c}\text { Number of customers } \\
\text { (total of 200) }\end{array}$ \\
\hline Masculine & 74 \\
\hline Feminine & 126 \\
\hline
\end{tabular}

Table 5: $\quad$ Monthly family income of passenger (in Euros) 1 Euro $=2.28$ Brazilian Reais.

\begin{tabular}{|c|c|}
\hline $\begin{array}{c}\text { Monthly family income of passenger } \\
\text { (Euros) }\end{array}$ & \begin{tabular}{c} 
Number of customers (total of 200) \\
\hline Less than 195 (minimum wage)
\end{tabular} \\
\hline 195 (minimum wage) & 3 \\
\hline 196 to 390 & 49 \\
\hline 391 to 585 & 50 \\
\hline 586 to 780 & 14 \\
\hline 780 to 975 & 13 \\
\hline 976 to 1,170 & 7 \\
\hline 1,170 to 1,365 & 3 \\
\hline Above 1,365 & 10 \\
\hline Didn't know & 11 \\
\hline
\end{tabular}

Table 6: Handicap special needs.

\begin{tabular}{|c|c|}
\hline Handicap Passenger & $\begin{array}{c}\text { Number of Customers } \\
\text { (total of 200) }\end{array}$ \\
\hline Yes & 0 \\
\hline No & 200 \\
\hline
\end{tabular}


Table 7: $\quad$ Educational level.

\begin{tabular}{|c|c|}
\hline Educational level & Number of Customers (total of 200) \\
\hline Illiterate & 1 \\
\hline Incomplete first grade & 18 \\
\hline First grade & 2 \\
\hline Incomplete high school & 42 \\
\hline High school & 58 \\
\hline Incomplete college degree & 39 \\
\hline College degree & 40 \\
\hline
\end{tabular}

Table 8: $\quad$ Reasons to travel.

\begin{tabular}{|c|c|}
\hline Reasons to travel & Number of Customers (total of 200) \\
\hline Study & 59 \\
\hline Work & 99 \\
\hline Shopping & 12 \\
\hline Sightseeing & 6 \\
\hline Multiple reasons & 24 \\
\hline
\end{tabular}

Table 9: $\quad$ Travel frequency.

\begin{tabular}{|c|c|}
\hline Travel frequency & Number of Customers (total of 200) \\
\hline Daily & 140 \\
\hline Once a week & 1 \\
\hline Twice or more a week & 6 \\
\hline As necessary & 53 \\
\hline
\end{tabular}

Table 10: Worst day to travel in the opinion of the customer.

\begin{tabular}{|c|c|}
\hline Worst day to travel & Number of Customers (total of 200) \\
\hline Weekdays & 74 \\
\hline Weekend & 123 \\
\hline Indifferent & 3 \\
\hline
\end{tabular}

Table 11: $\quad$ Number of times traveled per day.

\begin{tabular}{|c|c|}
\hline Travel frequency & Number of Customers (total of 200) \\
\hline Once & 10 \\
\hline Twice & 115 \\
\hline Three times & 9 \\
\hline Four times & 28 \\
\hline More than four times & 4 \\
\hline Occasionally & 34 \\
\hline
\end{tabular}


Table 12: $\quad$ Worst time to travel in the opinion of the customer.

\begin{tabular}{|c|c|}
\hline Worst time to travel & Number of Customers (total of 200) \\
\hline Morning & 66 \\
\hline Afternoon & 58 \\
\hline Night & 72 \\
\hline Indifferent & 4 \\
\hline
\end{tabular}

Table 13: $\quad$ Manner of paying fare.

\begin{tabular}{|c|c|}
\hline Manner of paying fare & Number of Customers (total of 200) \\
\hline Pre-paid discount card & 41 \\
\hline Full fare & 123 \\
\hline Students & 29 \\
\hline Free pass & 7 \\
\hline
\end{tabular}

\section{Quality level}

Using the results obtained from Table 2 and applying the same calculation procedure presented in a previous paper by De Souza et al. [1], we can determine the overall quality level of the service provided by Itaperuna's bus company. These results could be used in the future to evaluate if Itaperuna's bus company has improved its service and fulfilled its customer's needs. In a future paper we will compare the overall quality level of the service provided by Itaperuna's bus company with the one previously taken of Rio Branco's bus company.

To determine the overall quality level the following steps should be followed:

1. Determine the total number of customers that:

a. $\mathrm{S}_{\mathrm{g}}$; considered the items researched as good;

b. $\mathrm{S}_{\text {ave }}$; considered the items researched as average;

c. $\mathrm{S}_{\mathrm{b}}$; considered the items researched as bad.

The following weights were used for each of the classifications:

d. Good: $p_{g}=2$;

e. Average: $\mathrm{p}_{\mathrm{ave}}=1$;

f. Bad: $\mathrm{p}_{\mathrm{b}}=0$.

2. Multiply the obtained values for each of the classifications by its corresponding weights. As a result we will have the overall quality level (OQL) given by eqn. (1):

$$
\mathrm{OQL}=\mathrm{S}_{\mathrm{g}} \times \mathrm{p}_{\mathrm{g}}+\mathrm{S}_{\mathrm{ave}} \times \mathrm{p}_{\mathrm{ave}}+\mathrm{S}_{\mathrm{b}} \times \mathrm{p}_{\mathrm{b}}
$$

Now, with $p_{g}=2, p_{a v e}=1$ and $p_{b}=0$, we will have:

$$
\mathrm{OQL}=2 \mathrm{~S}_{\mathrm{g}}+\mathrm{S}_{\mathrm{ave}}
$$

3. Compare the obtained OQL value with the "maximum theoretical value" that eqn. (2) could have, that is, the total number of items multiplied by the 
number of customers surveyed (in this work, 16 items and 200 customers researched), multiplied by 2 , the corresponding weight for the classification "good." Since in an "optimal theoretical case" all the customers surveyed will give the classification "good" to all the items researched, the value of $\mathrm{S}_{\mathrm{ave}}$ in eqn. (2) will be equal to zero. This comparison is given by:

$$
\mathrm{OQL} \leq \mathrm{T}_{\mathrm{V}}=2 \times 16 \times \mathrm{n}
$$

Here, $n$ is the number of customers researched (200), $\mathrm{T}_{\mathrm{V}}$ is the "optimal theoretical value" that eqn. (3) could have, 2 is the corresponding weight for the classification "good" and 16 is the number of items surveyed in this work. Then:

$$
\mathrm{T}_{\mathrm{V}}=2 \times 16 \times \mathrm{n}
$$

4. Now, to compare the obtained OQL value with the "maximum theoretical value" that eqn. (2) could have, we will use the following classification:

a. If the OQL value is located between $90 \%$ and $100 \%$ of the $\mathrm{T}_{\mathrm{V}}$ value: the service level is considered to be "good"; the customers' needs are being fulfilled. The bus company should keep up the good work.

b. If the OQL value is located between $70 \%$ and $89 \%$ of the $\mathrm{T}_{\mathrm{V}}$ value: the service level is considered to be "satisfactory". However, the service level should be improved in order to exceed the customers' expectation.

c. If the OQL value is located between $40 \%$ and $69 \%$ of the $\mathrm{T}_{\mathrm{V}}$ value: the service level is considered to be "reasonable", but there are complaints about some areas of service rendered by the bus company.

d. If the OQL value is located between $10 \%$ and $39 \%$ of the $T_{V}$ value: the service level is considered to be "bad", and urgent measures should be taken by the bus company in order to continue operating.

e. If the OQL value is located below $10 \%$ : the service level is considered to be "very bad". The city authorities should immediately consider canceling the bus company's concession.

\section{The overall quality level for the bus company}

Using eqn. (2), with $\mathrm{S}_{\mathrm{g}}=589, \mathrm{~S}_{\mathrm{ave}}=1,258$ and $\mathrm{S}_{\mathrm{b}}=1,353$, we will have:

$\mathrm{S}=2 \mathrm{~S}_{\mathrm{b}}+\mathrm{S}_{\mathrm{re}}+0 \times \mathrm{S}_{\mathrm{b}}=2 \times 589+1,258=1,178+1,258$. Then: $\mathrm{S}=2,436$

Verifying if $\mathrm{S} \leq \mathrm{T}_{\mathrm{V}}$ :

$\mathrm{T}_{\mathrm{V}}=2 \times 16 \times \mathrm{n}=2 \times 16 \times 200=6,400$. As a result, $\mathrm{S} \leq \mathrm{T}_{\mathrm{V}}$, since $2,436 \leq 6,400$.

Therefore: $\mathrm{S}=2,436$, which represents $38.06 \%$ of $\mathrm{T}_{\mathrm{V}}$.

This overall quality level (OQL) value of $38.06 \%$ is located between $10 \%$ and $39 \%$ of the $T_{V}$ value. The service level is considered to be "bad", and urgent measures should be taken by the bus company in order to continue operating.

\section{Conclusions}

The bus company located in Itaperuna needs to take measures in order to raise their service level. They should initially focus their efforts on the items that have presented the "worst" evaluation by their customers. Their service level is 
considered to be "bad," and urgent measures should be taken by them in order to continue operating. The analysis of the survey answered by the Itaperuna's bus company customers has shown that some of the conditions considered in the questionnaire associated with customer satisfaction given by Table 2 need to be urgently improved, especially the ones related to fare, waiting time at the bus stop, interval between buses and scheduling, all these conditions showing a bad evaluation greater than $50 \%$. The lack of interest by the bus company in customer satisfaction is the main reason for loss of passengers to informal and alternative forms of transportation, such as: personal car, motorcycle-taxi, private bus and travel by foot or by bicycle. The bus company needs to immediately begin the process of changing their attitude in order to improve the quality of their service. They should focus on customer satisfaction, or their future operations could be bleak.

Some of the problems found in this study will demand time and money to be solved or at least, eased. They should determine among the analyzed conditions, which ones they could improve in the nearby future by themselves, and which ones will need to have help from the city or state government to be improved.

\section{References}

[1] De Souza, Daniel I., Kipper, D. A \& Duarte, P. (2010). Suggestions toward quality improvement in public transportation service in Rio Branco, Acre, Brazil, Urban Transport 2010 conference, WIT Transactions on Ecology and the Environment, Volume111, pp. 115-124, Southampton and Boston, 2010.

[2] NTU (2003). National urban transport association year book 2001/2002.http://www.ntu.ogr.br/publicacoes/anu_2001_2002/2002.

[3] NTU (2007). National urban transport association year book 2006/2007.

[4] NTU (2010). National urban transport association year book 2009/2010. http://www.ntu.ogr.br/. 